\title{
CONTRACT FARMING AND THE EFFECT ON PRICE RISK IN BROILER FARMING
}

\author{
Adinda Tissa Rachmasari Putri ${ }^{1}$, and Mohammad Rondhi ${ }^{1^{*}}$ \\ ${ }^{1}$ Department of Agribusiness, Faculty of Agriculture, Jember University, Indonesia
}

\begin{abstract}
Contract farming is one of the ways in a production relationship that is carried out by at least two parties who work together for a certain unit of time arranged in a written or oral agreement. Contracts in agriculture are carried out to reduce the risks faced by both parties. There are several agriculture commodities developed under the contract farming system, one of which is broiler. Broiler are important for fulfilling animal protein. High consumption in Indonesia at 2012-2016, not supported by production and the price of broiler has large fluctuations. Large fluctuations in Jember at 2012-2016 illustrate the magnitude of the risk in broiler farming both the risk of production and price. The amount of risk borne by farmerss causes easy contract farming to be applied in broiler chicken farming. This study purpose to see: (1) The pattern of contract farming carried out on broiler farming; and (2) The effect of contract farming on the price risks faced by farmerss. Method of determining the research area is purposive method. The research method is carried out by descriptive and analytical. The method of data collection is by interview, observation and secondary data with the use of recapitulation of the results of farmers maintenance. Determination of respondents was conducted randomly at farmerss in Jember Regency. The results of the study show: 1) The pattern of contract farming carried out on broiler farming is a contract farming with the type of production contract; and (2) The effect of contract farming causes the risk faced by farmerss to be reduced by $39 \%$ than independently farmerss.
\end{abstract}

\section{INTRODUCTION}

Contract farming occurred between a small farmers and a big company will give benefit for both of them, without sacrificing other sides. Contract farming is also believed as a tool to transfer technology and create economic stability by income distribution (Rustiani, 1997). MacDonald and Korb (2011) explained that many ways in transferring agricultural product where the flow will be regulated through an agreement between the farmerss and the company which have a role as a buyer where that agreement will be agreed before the production is done. Contract farming gives a closer relationship between the farmers and the buyer than the relationship of the farmers with the buyer on the spot market and allows the company to do a bigger control on the decision of production and agricultural processes.

Rustiani (1997) and Zhang (2012) stated that contract farming is one of the ways in the production relationship which is done at least by two parties which do cooperation to one certain time controlled in one agreement in writing as well as oral. In this relationship, each party uses the resource they are expert. Where contract farming is divided into 2 types that are production contract and marketing contract. The production contract is used widely in livestock production and marketing contract is important for plant production (Mac Donald and Korb, 2011).

If reviewed more, principally, contract farming is nothing else a risk distribution mechanism (Oya, 2012). Rustiani (1997), ideally a contract relationship in agriculture is done to decrease the risk faced by both sides. Pugo (2018), the contract will decrease the risk faced by the company if it must count on the raw material fully from an open market. The main company also receives another benefit because they do not have to invest over the land and manage the wide agriculture. For the livestock side itself, contract farming will solve the general problem they face in the process of risktaking. Risk source from the agriculture done is generally caused by uncertain input and output prices (Erkan, 2018). Glover (1990), stated the problem faced by the farmerss generally as follows:

1. The difficulty to face the competition with another producer which has adopted new technology.

2. The weakness of the input supply condition in terms of quantity and continuity.

3. Weak agricultural counseling.

4. The difficulty on the credit.

5. The market for the agricultural commodity is limited so that it tends to have unpredictable price.

6. International market with a better price than the local market is hard to access by the small farmers.

As time goes by, the innovation of agricultural institution especially the existence of contract farming can be received in the agricultural sector in Indonesia. There are some commodities developed under the system of contract farming, one of them is broiler chicken. Broiler chicken becomes an important commodity which becomes the society's mainstay for the fulfillment of animal protein (Directorate General of Livestock and Animal Health, 2017). This causes the consumption of broiler chicken is high which also needs a higher production again. However, the production and the price of broiler chicken have big fluctuation (BPS, 2018). Big fluctuation illustrates that there is a big risk in the livestock business of broiler chicken either in the production risk or price risk.

The high risk burdened by the farmers causes easy contract farming to apply and accept in the livestock business of broiler chicken. Remembering the important production of broiler chicken on the national economy, then broiler chicken needs processing with a good system. Therefore, the farmers has to select a type of good cooperation pattern where the farmers's right can 
be protected and the selling price in the farmers level keep being maintained in an optimal point and tend to be more stable although having a high risk. Thus, it can be seen that contract farming has a benefit and makes it important in the livestock business of broiler chicken. However, in the implementation, the risk is often faced by the farmers though having followed contract farming. Little attention focusing on the reason or resource for the risk faced by the producer. Where there are some reasons why producer may still face the risk such as that the contract occurred maybe still not efficient (Hueth and Ligon, 1999).

The previous research which has been done by Arifanah (2017) states that the cooperation occurred between the farmers with the company is the main pattern of plasma. The same research is done by Febriandika, et al (2017) which states that the cooperation occurred is classified in the main pattern of plasma. The research which has been done focuses to see the right and the obligation happened. Different from the previous research, to see the cooperation occurred is not only based on the existing pattern on the government regulation because there is still cooperation not suitable with the pattern existing on the government regulation.

Specifically, this research aims to analyze the type of cooperation intertwined between broiler chicken farmers with the company and also to see the effect of contract farming on the price risk faced by the farmers. This research is expected to be able to be a consideration to fix the contract farming as a tool to regulate the cultivation process as well as the marketing so that the design of play rules is more efficient and can build equality between the parties involved.

\section{RESEARCH METHODS}

The determination of research was done by using the purposive method in Jember Regency, East Java Province, Indonesian. The research method done was descriptive and analytic. The sample retrieval method was done by purposive where the farmers doing a contract the total of the sample is 35 farmers. The sample decision of partner farmers selected into respondent in this research was the farmers who did a contract with PT. XYZ in Jember Regency.

In this research regarding the implementation of contract farming between broiler chicken farmers with the company in Jember Regency was analyzed by descriptive method. The descriptive method was used to explain and describe data and information from the result of interview and observation activities. Where it will describe the intertwining process of contract farming from the beginning until the end. Covering right and obligation from the farmers as well as the process before the agreement, in the cultivation process until the final process. From the description, then contract farming done will be able to be grouped into an existing pattern.

This research is about the effect of contract on the price risk faced by broiler chicken farmers in Jember Regency. The effect of contract on the price risk can be seen from the difference or the comparison between the daily price obtained from the agreement of cooperation when doing a contract with the market price currently valid when doing independently or without doing the contract is called by standard deviation ratio (Knoeber, 1995). Where the price compared is obtained from secondary data where the daily price if following the contract farming and the daily price if not following the contract will be contained within the recapitulation of maintenance result (RHPP).

Knoeber (1995), thus the price obtained by the partner farmers can be calculated by the equation as follows:

$$
\alpha_{c t}=\alpha_{c}+\left[0, \beta\left(\alpha_{m}-\alpha_{c e}\right)\right](1)
$$

$\alpha_{\mathrm{ct}}=$ Price is received by the farmers at a period of

$\mathrm{t}$

$\alpha_{\mathrm{c}} \quad=$ Price at cooperation contract

$\alpha_{\mathrm{m}} \quad=$ Market price currently valid

$\beta=$ Market bonus, when the market price is higher (0.35)

When the market price is higher than the contract price then the equation will become $\left[\beta\left(\alpha_{m}-\alpha_{c}\right)\right]$. When the market price is lower than the contract price then the equation will become $\left[0\left(\alpha_{\mathrm{m}}-\alpha_{\mathrm{c}}\right)\right]$. To see the actual price when the farmers does not make a contract then a simulation is done where the price calculated is only the market price currently valid To see the market price is obtained from the contract price added by the difference between the contract price with the market price can be seen from the existing market bonus.

\section{RESULT AND DISCUSSIONS}

\section{1 contract farming}

The analysis on the occurring contract farming is based on the contract substance which has been agreed. Agreed contract substance contains right and obligation for both sides involved. The following are the right and obligation of the economic actor in contract farming of broiler chicken. 
Table 1. Right and Obligation of Partner Farmers with the Company

\footnotetext{
Right and Obligation of Company

a) Loan the production facilities (DOC, feed, drug, and vitamin corresponding to the quality standard, total, time, and price) that have been determined.

b) Give counseling, service, and monitoring on the farmers.

c) Buy and pay all results of broiler chicken from the partner farmers.

d) Give a performance bonus to the farmers if fulfilling the performance requirement set by the company.

e) Take back the chicken which has been already harvested with the weight that has been determined.

f) Cut the production result of partner farmers with the cost for cultivation that is DOC, feed, drug, and vitamin which becomes a burden of partner farmers.

g) Do monitoring and review anytime.
}

Right and Obligation of Partner Farmers

a) Fill in the form of registration data and give warranty to the partner company.

b) Serve the cage and the equipment and the labor.

c) Do cultivation of chicken according to the guidance set by the partner company.

d) Save feed, drug, and vitamin and write down the condition and number of users.

e) Maintain the caliber, quality, safety, and chicken health.

f) Sell all production results in the form of broiler chicken to the partner company based on the contract price that has been set.

g) Pay all debts to the partner company because of the use of production facilities served by the partner company.

h) Get the production facilities in the form of DOC, feed, drug, and vitamin.

i) Get technical counseling from the partner company.

j) Get the payment of selling results from broiler chicken which has been reduced by the debt of production facility.
The monitoring result shows that the partner company is the party who serve livestock production facilities, technical counseling, operational management, and marketing broiler chicken produced by the partner farmers. Partner company gives the production facilities to partner farmers with an agreement that all yields will later be bought by the partner company and partner farmers is not allowed to sell the yields to another side to the partner company side. The technical counseling done by PPL is done once a week.

The partner farmers is required to fill in the agreement form and gives warranty to the partner company. Frequently, the partner farmers does not give warranty but only in the form of a stamped statement letter. The partner farmers is required to buy and use chicken seedling (DOC), feed and chemical vaccine drug from the partner company, apart from three inputs then the farmers is free to buy the input outside the partner company. The production facilities given by the company is not allowed to move hands to another side.

The partner farmers is necessary to serve land as a place to do the cultivation as well as the cage, cultivation equipment, and labor who will do the activity of cultivation process. The partner farmers also does a cage preparation independently but will be a role of a partner company in giving counseling about the conformity standard before the cultivation of broiler chicken has been done and will be a survey related to the conformity. The existence of technical counseling from the partner company can increase the performance and ability of partner farmers. The company side hands overall responsibilities of the production process to the partner farmers with the final goal of maximal broiler chicken yield corresponding to the standard of the partner company.

The partner farmers only needs to serve the land, cage, equipment, and labor while the partner company side is involved further in the production process. The partner company side determines the type and number of a commodity that has to be given, the partner company side also determines the type of variety and production method. Partner companies usually give technical support and serve production facilities. The partner company side can control the decision for the use of production facilities, operational, and marketing.

The selling price of broiler chicken from the farmers to the partner company is assessed based on the average weight of living chicken produced by the partner farmers that the heavier the average weight of living chicken harvested the highest the price received by the farmers. Broiler chicken sold from the partner farmers is all broiler chickens entrusted by the company to the partner farmers. The farmers's income is also affected by the performance of partner farmers. The following is the bonus which will be received by the partner farmers:

1. If the difference of actual FCR with standard FCR is less than or equal with 0.075 then will get a bonus of IDR $50 / \mathrm{kg}$. 
2. If the difference of actual FCR with standard FCR is less than or equal with 0.000 then will get a a bonus of IDR $100 / \mathrm{kg}$.

3. If the market price is higher than the contract price then the farmers will get the difference in the market price

4. If the death rate or depletion is less than $5 \%$ of the population, then the partner farmers will get a depletion bonus as big as IDR 50/tail.

5. If the diseased chicken then the price of the diseased chicken is the market price if the price is less than the contract price.

6. If the market price is less than the contract price, and the partner farmers's income is more than IDR 3.000/tail then the excess of meat will be purchased with the market price.

7. Incentive closed house is given as big as IDR $100 / \mathrm{kg}$.

Based on the contract process that has been explained and done by the partner farmers of broiler chicken with the partner company is a contract production. This is according to Rustiani (1997) has said, that the contract production where the company can control the farmers's decision in the use of production facilities and production method. This is also in line with what was told by (MacDonald and Korb (2011); Otsuka (2016)), that the contract pattern corresponding to livestock commodity is the production contract.

\section{2 the effect of contract farming on the price risk}

Contract farming is one of the mechanisms of risk distribution. Risk in the marketing failure of production result and risk of price fluctuation will shift from the farmers to the partner company. It is because on the final profit will be shared by both sides so if the failure occurred on the marketing or the low price then will be felt by both the farmers and the company. The following is descriptive statistic data used which can be seen in table 2 .

Table 2. Descriptive Statistic Data

\begin{tabular}{lrrr}
\hline \multicolumn{1}{c}{ Variable } & \multicolumn{1}{c}{ Mean } & \multicolumn{1}{c}{ Max } & \multicolumn{1}{l}{ Min } \\
\hline $\begin{array}{l}\text { Production (kg) } \\
\begin{array}{l}\text { Contract } \\
\text { (IDR/kg) }\end{array}\end{array}$ & 3,491 & 11,526 & 35 \\
$\begin{array}{l}\text { Market } \\
\text { (IDR/kg) }\end{array}$ & 17,548 & 21,833 & 9,558 \\
$\begin{array}{l}\text { Contract } \\
\text { reception (IDR) }\end{array}$ & 17,837 & 24,164 & 9,398 \\
$\begin{array}{l}\text { Market } \\
\text { reception (IDR) }\end{array}$ & $63,287,380$ & $211,491,336$ & 379,500 \\
\hline
\end{tabular}

Sources: Secondary Data processed (2018)

It can be seen in Table 2 that the market price is indeed higher than the contract price obtained when doing the contract. Lower contract price causes the farmers reception also lower than when they do it independently. It is caused when doing by partnership then will occur a profit-sharing between the company with the farmers therefore, the reception when partnering is lower than when doing it independently.

The effect of contract farming on the risk of price fluctuation can be seen from the difference or the comparison between the price obtained from the farmers if partnering and if the farmers does independently. The difference is caused by the different price obtained where for the partner farmers will get agreed price from the cooperation agreement when doing the contract farming while getting the market price recently applicable when doing independently or without doing contract farming. Thus, there are two values of deviation standard when the farmers follows the contract farming or the real price and when the farmers does the livestock business independently or simulation price.

Deviation standard ratio can show the variability from the price obtained by the farmers that the bigger the deviation standard ratio then the bigger the variability will be got by the farmers. Bigger deviation standard shows that the price, as well as the risk gained, is bigger. The comparison result of the deviation standard between the real price and simulation result can be seen in table 3 .

Table 3 The Comparison of Deviation Standard between the Real Reception and Simulation Reception

\begin{tabular}{|c|c|c|c|}
\hline & Value & Risk & Description \\
\hline $\begin{array}{l}\text { Average } \\
\text { Deviation } \\
\text { Standard of } \\
\text { Simulation } \\
\text { Price }\end{array}$ & 3,487 & $100 \%$ & $\begin{array}{l}\text { The farmers } \\
\text { price if not } \\
\text { partnering }\end{array}$ \\
\hline $\begin{array}{l}\text { Average } \\
\text { Deviation } \\
\text { Standard of } \\
\text { Real Price }\end{array}$ & 2,116 & $61 \%$ & $\begin{array}{l}\text { The farmers } \\
\text { price if } \\
\text { partnering }\end{array}$ \\
\hline Risk Shifting & 1,371 & $39 \%$ & $\begin{array}{l}\text { Shifting risk } \\
\text { from the } \\
\text { farmers to the } \\
\text { company }\end{array}$ \\
\hline
\end{tabular}

Sources : Secondary Data processed (2018)

From table 3 can be known that the deviation standard of simulation price is 3.487 while for the deviation standard the real price is 2.116 . It shows that the price fluctuation when the simulation or independent breeding is higher than when doing a contract. The risk gained when the farmers does independently will bear the risk as big as $100 \%$. The difference between the deviation standard of simulation with the reality is 1.371 where that value is $39 \%$ of the deviation standard of simulation, it shows that by the existing of contract occurred the decrease of the price fluctuation where there is a risk diversion of price fluctuation to the company as big as $39 \%$ so that the partner farmers bears the risk smaller than when the farmers does independently where the risk that will be borne by the farmers will be $61 \%$. It was also mentioned by (Knoeber (1995); Otsuka (2016); Khasan (2018); Saenger (2013)), that by the existence of contract causes the price risk will 
shift from the farmers to company. Rustiani (1997), also mentioned that the contract is an effort for the farmers in avoiding higher risk where there is a risk of marketing failure and risk of price fluctuation that can be diverted from the farmers to the company. The comparison of fluctuation between independent farmers with the partner farmers can be seen in figure 1 .

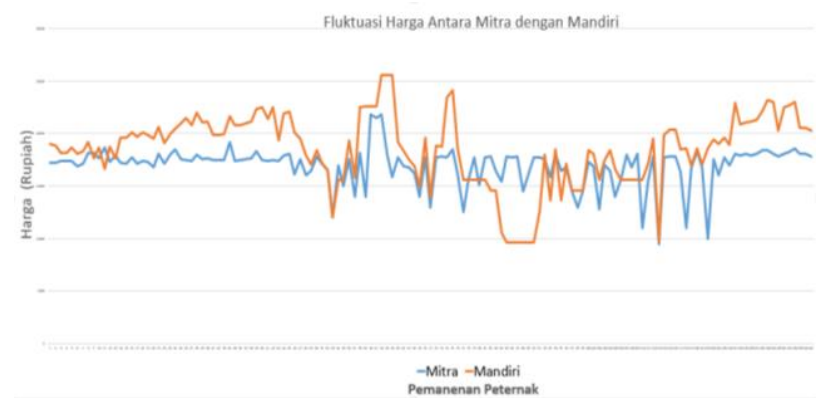

Figure 1. The Comparison of Fluctuation between Independent Farmers with the Partner Farmers

\section{CONCLUSIONS}

Contract farming occurred between the farmers with the company is included in the type of production contract that it is based on the contract agreement letter and the process of the contract. Broiler chicken farmers has a role to serve land area and the cage, to serve the equipment of cage, to serve labor, to do the cultivation, and to sell all the production results to the partner company, while the partner company has a task to give the loan of production facilities, to give technical counseling and coaching, and to purchase all the production results of the farmers. The effect of contract farming on the price risk faced by broiler chicken farmers is the occurrence of price risk shifting from the farmers to the partner company as big as $39 \%$ so that the risk borne by the farmers is smaller when the farmers does the livestock business independently.

\section{REFERENCES}

1. Arifanah, L. Kajian Pola Kemitraan dan Pendapatan Pada Peternak Ayam Broiler di Kecamatan Sukowono Kabupaten Jember. Universitas Jember. (2017)

2. Badan Pusat Statistika. Jwa Timur dalam Angka. Surabaya: BPS JAwa Timur. (2018)

3. Direktorat Jenderal Peternakan dan Kesehatan Hewan. Statistik Peternakan dan Kesehatan Hewan 2017. Jakarta: Direktorat Jenderal Peternakan dan
Kesehatan Hewan Kementerian Pertanian RI. (2017)

4. Febriandika, B., Iskandar, S., \& Afriyatna, S. Studi Pola Kemitraan Usaha Peternakan Ayam Ras Broiler (Broiler) Di Desa Gelebak Dalam Kecamatan Rambutan Kabupaten Banyuasin. SOCIETA, 6(1), 57-65. (2017).

5. Glover, D., \& Kusterer, K. Small Farmerss, Big Business: Contract Farming and Rural Development. David Glover. Ken Kusterer. In Economic Development and Cultural Change. (1990)

6. Hueth, B. dan E. Ligon. Producer Price Risk and Quality Measurement. American Journal Agriculture and Economics, 3(81): 512-524. (1999).

7. Khasan, A., Rondhi, M., Aji, J.M.M.. Who Bear the Most Risk? Risk and Risk Shifting in Indonesian Broiler Contract. Preprints 2018, 2018100020 (doi: 10.20944/preprints201810.0020.v1). (2018)

8. Knoeber, Charles R. And Walter N. Thurman. Don't Conut Your Chickens: Risk and Risk Shifting in Broiler Industry. Amer. J. Agr. Econ. 486-496. (1995)

9. MacDonald, J., dan P. Korb. Agricultural Contracting Update: Contracts in 2008. USDA, Economic Research Service, Economic Information Bulletin No. 72. (2011)

10. Otsuka, K., Nakano, Y., \& Takashi, K. Contract Farming ini Developed and Developing Countries. SSRN, (June), 1-24. (2016).

11. Oya, C. (2012). Contract Farming in Sub-Saharan Africa: A survey of Approches, Debates and Issues. Journal of Agrarian Change, 12(1): 1-33.

12. Pugo, A. G., R. Birner, \& S. Gupta. Making Contract Farming Arrangements Work in Africa's Bioeconomy: Evidence from Cassava Outgrower Schemes in Ghana. Sustainbility, (May), 1-21. (2018)

13. Rustiani, F., H. Sjaifudian dan R. Guanawan. Mengenal Usaha Pertanian Kontrak (Contract Farming). Bandung: Yayasan AKATIGA. (1997)

14. Saenger, C., Qaim, M., Torero, M., \& Viceisza, A. Contract Farming and Smallholder Incentives To Produce High Quality: Experimental Evidence from The Vietnamese Dairy Sector. Agricultural Economics (United Kingdom), 44(3), 297-308. (2013)

15. Zhang, Qian F. The Political Economy of Contract Farming ini China's Agrarian Transition. Journal oh Agrarian Change, 12(4): 460-483. (2014) 